\title{
Clostridium acetobutylicum grows vegetatively in a biofilm rich in heteropolysaccharides and cytoplasmic proteins
}

\author{
Dong Liu ${ }^{1,2+}$, Zhengjiao Yang ${ }^{1 \dagger}$, Yong Chen ${ }^{1,2}$, Wei Zhuang ${ }^{1,2}$, Huanqing Niu ${ }^{1,2}$, Jinglan $\mathrm{Wu}^{1,2}$ \\ and Hanjie Ying ${ }^{1,2^{*}}$ (1)
}

\begin{abstract}
Background: Biofilms are cell communities wherein cells are embedded in a self-produced extracellular polymeric substances (EPS). The biofilm of Clostridium acetobutylicum confers the cells superior phenotypes and has been extensively exploited to produce a variety of liquid biofuels and bulk chemicals. However, little has been known about the physiology of C. acetobutylicum in biofilm as well as the composition and biosynthesis of the EPS. Thus, this study is focused on revealing the cell physiology and EPS composition of C. acetobutylicum biofilm.

Results: Here, we revealed a novel lifestyle of $C$. acetobutylicum in biofilm: elimination of sporulation and vegetative growth. Extracellular polymeric substances and wire-like structures were also observed in the biofilm. Furthermore, for the first time, the biofilm polysaccharides and proteins were isolated and characterized. The biofilm contained three heteropolysaccharides. The major fraction consisted of predominantly glucose, mannose and aminoglucose. Also, a great variety of proteins including many non-classically secreted proteins moonlighting as adhesins were found considerably present in the biofilm, with GroEL, a S-layer protein and rubrerythrin being the most abundant ones.

Conclusions: This study evidenced that vegetative C. acetobutylicum cells rather than commonly assumed sporeforming cells were essentially the solvent-forming cells. The abundant non-classically secreted moonlighting proteins might be important for the biofilm formation. This study provides the first physiological and molecular insights into $C$. acetobutylicum biofilm which should be valuable for understanding and development of the biofilm-based processes.
\end{abstract}

Keywords: Clostridium acetobutylicum, Biofilm, Polysaccharide, Moonlighting protein, Sporulation

\section{Background}

Microbial cells could synthesize extracellular polymeric substances (EPS) to build biofilm communities with enhanced survival and metabolic capacities [1]. In natural settings, biofilms are commonly formed by cells attached to surfaces or interfaces, like the surfaces of water pipes, stones in a river, and indwelling

\footnotetext{
*Correspondence: yinghanjie@njtech.edu.cn

${ }^{\dagger}$ Dong Liu and Zhengjiao Yang contributed equally to this work

${ }^{1}$ State Key Laboratory of Materials-Oriented Chemical Engineering, College of Biotechnology and Pharmaceutical Engineering, Nanjing Tech University, No. 30, Puzhu South Road, Nanjing 211800, China

Full list of author information is available at the end of the article
}

devices in hospital patients. In laboratory, biofilms are usually attached to the inside wall of incubators, grown on agar plates or static liquid surfaces [2], and their formation could often be facilitated by solid carriers submerged in culture media, such as cotton fibre, plastic, stainless steel, glass or clay brick [3, 4]. Some nutritional factors were shown to be important for biofilm formation by some species. For some prokaryotes like Staphylococcus aureus, Pseudomonas aeruginosa and P. fluorescens, iron limitation repressed biofilm formation while high iron rescued biofilm formation [5, 6]. In Escherichia coli, Salmonella sp. and anaerobic sludge communities, low-nutrient media (e.g., 
glucose-minimum medium, minimum-salts medium, media with relatively less peptone or a high $\mathrm{C} / \mathrm{N}$ ratio) appeared to favor EPS production and biofilm formation [7-9]. As a multicellular form of microbial life, biofilms could exhibit emergent properties that are quite distinct from those of free-living cells and have attracted increasing attention in biotechnological processes as well as in medical processes [1]. More and more biofilms are engineered as cell factories for biomanufacturing [10]. One canonical example is the biofilm of solventogenic Clostridium acetobutylicum which is an important industrial platform capable of producing a range of biofuels and bulk chemicals [11]. It was shown that butanol tolerance of $C$. acetobutylicum cells in biofilm was three orders of magnitude higher than that of planktonic cells under certain conditions [12]. Operated in a continuous mode, Clostridium biofilms increased the productivity by almost 50 -fold [4, 13]. Enhanced metabolism of pentose as well as hexose and enhanced solvent biosynthesis were also extensively demonstrated for $C$. acetobutylicum biofilm [14-16].

In general, superior phenotypes (such as the improved tolerance and metabolic activities) of EPSencased biofilm cells could be attributed to two aspects: genetic regulation and EPS architecture. Living together in biofilms, cells tend to exhibit a different pattern of gene expression. Some genes are repressed or activated, thus cellular structure and functions are modulated $[17,18]$. On the other hand, highly hydrated EPS matrix can be a protective barrier and provides cells with a favourable microenvironment. EPS plays an important role in exclusion of toxic substances $[17,19]$. It keeps cells in close proximity and enables the development of high-density cell communities with intense cell-cell communication and cooperation $[19,20]$. EPS matrix also provides excellent conditions for retention of extracellular proteins, functioning as an enzyme reservoir for external processes [1].

However, so far little has been known about $C$. acetobutylicum biofilm. Despite the observation of $C$. acetobutylicum biofilm under various conditions, the underlying molecular basis and regulatory processes remain to be explored [21]. Deciphering the EPS matrix and cell physiology in the biofilm will be important for optimization and control of biofilm-based processes. Recently we reported the first transcriptomic study of C. acetobutylicum biofilm [22] and revealed that heterogeneity of $C$. acetobutylicum EPS conferred improved resistance to harsh environments [23]. In this study, we will further shed light on $C$. acetobutylicum biofilm by investigating the cell physiology and EPS composition in the biofilm.

\section{Methods}

\section{Culture and medium}

Cultures of C. acetobutylicum B3 (CGMCC 5234) were grown in modified P2 medium containing $10 \mathrm{~g} / \mathrm{L}$ glucose as the sole carbohydrate source for seed culture. Fermentation experiments were performed anaerobically in 2-L stainless steel columns containing $1.5 \mathrm{~L}$ of P2 medium (glucose $60 \mathrm{~g} / \mathrm{L} ; \mathrm{K}_{2} \mathrm{HPO}_{4} 0.5 \mathrm{~g} / \mathrm{L} ; \mathrm{KH}_{2} \mathrm{PO}_{4}$ $0.5 \mathrm{~g} / \mathrm{L} ; \mathrm{CH}_{3} \mathrm{COONH}_{4} 2.2 \mathrm{~g} / \mathrm{L} ; \mathrm{MgSO}_{4} \cdot 7 \mathrm{H}_{2} \mathrm{O} 0.2 \mathrm{~g} / \mathrm{L}$; $\mathrm{MnSO}_{4} \cdot \mathrm{H}_{2} \mathrm{O} 0.01 \mathrm{~g} / \mathrm{L} ; \mathrm{NaCl} 0.01 \mathrm{~g} / \mathrm{L} ; \mathrm{FeSO}_{4} \cdot 7 \mathrm{H}_{2} \mathrm{O}$ $0.01 \mathrm{~g} / \mathrm{L} ; p$-aminobenzoic acid $1 \mathrm{mg} / \mathrm{L}$; thiamine $1 \mathrm{mg} / \mathrm{L}$; biotin $0.01 \mathrm{mg} / \mathrm{L}$ ) at $37^{\circ} \mathrm{C}$ with initial inoculum $10 \%(\mathrm{v} / \mathrm{v})$. Cotton towel was used to facilitate the formation of biofilm and continuous culture was performed with broth replacement every $12 \mathrm{~h}$, see our previous work for details $[12,22]$.

\section{Quantification of biofilm formation}

Each piece of cotton towel $(2 \mathrm{~cm} \times 3 \mathrm{~cm})$ with attached biofilm was taken from fermenters at predetermined time, immersed in $20 \mathrm{~mL}$ of $0.1 \mathrm{M} \mathrm{NaOH}$ (the mass of $\mathrm{NaOH}$ solute was calculated as $W 1$ ) and vortexed to completely dissolve the biofilm. Then, the piece was removed and rinsed twice with a total of $40 \mathrm{~mL}$ of pure water. All the volumes were mixed together and the total volume was determined. Then, $3 \mathrm{~mL}$ of the mixture was dried and weighed to deduce the total dry weight (W2) of the mixture. Biofilm formation was quantified as $(W 2-W 1) /(2 \mathrm{~cm} \times 3 \mathrm{~cm})$.

\section{Transcriptomic analysis}

To collect biofilm cells for transcriptomic analysis, pieces of cotton towel were harvested from the fermenter typically at $6 \mathrm{~h}$ after each broth replacement and rinsed twice with PBS buffer $(137 \mathrm{mM} \mathrm{NaCl}, 2.7 \mathrm{mM} \mathrm{KCl}, 8 \mathrm{mM}$ $\mathrm{Na}_{2} \mathrm{HPO}_{4}$ and $2 \mathrm{mM} \mathrm{KH}_{2} \mathrm{PO}_{4}, \mathrm{pH} 7.4,4{ }^{\circ} \mathrm{C}$ ) to remove contaminating planktonic cells. Then, the cotton towel was submerged in 15-mL PBS buffer and the biofilm was scraped off the cotton towel. The resulting suspension was centrifuged at $8000 \times g$ for $6 \mathrm{~min}$ at $4{ }^{\circ} \mathrm{C}$ to pellet the biofilm cells. All the cells were frozen immediately using liquid nitrogen and then stored at $-80{ }^{\circ} \mathrm{C}$ prior to RNA extraction. RNA extraction and transcription analysis were performed as previously described [22]. Resulting microarray data were uploaded to the Gene Expression Omnibus (GEO) database under Accession Number GSE72765. Hierarchical clustering was performed using $\mathrm{R}$-software and clusters were visualized with Tree-view [22].

\section{Microscopy}

Light microscopy was used for morphological observation. Each piece of cotton towel (approximately 
$2 \mathrm{~cm} \times 3 \mathrm{~cm}$ ) with attached biofilm was taken from fermenters at predetermined time points, immersed in $0.1 \mathrm{M} \mathrm{NaOH}$ at $4{ }^{\circ} \mathrm{C}$ for $10 \mathrm{~min}$ and vortexed to completely disperse cells within the biofilm. Then, $50 \mathrm{ul}$ of suspension was transferred to a microscope slide and air-dried. Safranin $\mathrm{O}$ was used as a fluorescence dye that can be excited with green light [24]. It is well known for nuclear staining and was also reported to stain mucin, cartilage, starch and plant tissues [25]. In this study, it also differentially stained cells and endospores under light microscopy. Cells were stained with $0.5 \%$ safranin $\mathrm{O}$ for $30 \mathrm{~s}$, washed gently with water and then air-dried for light microscopy. As the real production system with cotton towel as biofilm carrier was not suitable for detailed observation of the biofilm, fluorescence microscopy using microscope slides as biofilm carriers was used to observe the biofilm in detail. Microscope slides were immersed in 100-mL Duran bottles containing $50 \mathrm{~mL}$ of fermentation broth at the time of inoculation $(10 \%, \mathrm{v} / \mathrm{v})$. All the bottles were kept static in an anaerobic system (Whitley DG250 workstation, Don Whitley Scientific Limited, UK) at $37^{\circ} \mathrm{C}$. After predetermined time intervals, the slides were withdrawn from the bottles, rinsed twice with PBS buffer ( $\mathrm{pH}$ 7.4), then air-dried in the anaerobic system. Samples were stained with $0.5 \%$ safranin $\mathrm{O}$ as described above before imaging in the green channel in a Leica DM2500 microscope.

\section{Extraction of polysaccharides and proteins from $C$. acetobutylicum biofilm}

Various methods were tried to dissolve C. acetobutylicum biofilm, including EDTA treatment, hot water treatment, sonication and enzymatic digestion. Usually, these methods could physically or chemically dissolve biofilm matrixes and have been commonly investigated for EPS extraction [26]. However, none of these methods could effectively dissolve the $C$. acetobutylicum biofilm except using $\mathrm{NaOH}$ (Additional file 1: Figure S1). The supernatant proteins and polysaccharides extracted by $\mathrm{NaOH}$ were much more than those from other methods, while the DNA ratio which could be an indicator of cell lysis was adequately low (Additional file 1: Table S1). Biofilm attached on cotton towel was immersed in $0.1 \mathrm{M} \mathrm{NaOH}$ at $4{ }^{\circ} \mathrm{C}$ for $30 \mathrm{~min}$. This would get the biofilm matrix dissolved completely and quickly. The suspension was then centrifuged $(10,000 \mathrm{~g})$ at $4{ }^{\circ} \mathrm{C}$ for $10 \mathrm{~min}$ to pellet cells. To the supernatant containing soluble EPS, 1.5 volume of ethanol was added to precipitate polysaccharides. Precipitated polysaccharides were collected through centrifugation and the supernatant was adjusted to $\mathrm{pH} 4.2$ and kept overnight at $4{ }^{\circ} \mathrm{C}$ to precipitate proteins. Interference of possible cell lysis on the process was excluded because cells were all apparently intact after the short treatment with $\mathrm{NaOH}$ as was confirmed by microscopy. Also, control experiments solely with an equal volume of $C$. acetobutylicum cells going through the same procedures did not yield apparent sediments.

\section{Isolation of polysaccharides}

An aliquot of $0.5 \mathrm{~g}$ wet polysaccharide extract was dissolved in $35 \mathrm{~mL}$ of $0.1 \mathrm{M} \mathrm{NaOH}$. The polysaccharide solution was filtered through a $0.45-\mu \mathrm{m}$ membrane filter (Fisher Scientific). Polysaccharides were isolated with the Q-Sepharose fast flow (QFF) chromatography column (AKTA, GE Healthcare, USA), eluted with a step gradient of $\mathrm{NaCl}$ (dissolved in $0.1 \mathrm{M} \mathrm{NaOH}$ ) in $0,0.3,0.4,0.6$, and $0.8 \mathrm{M}$ steps, at a flow rate of $1.5 \mathrm{~mL} / \mathrm{min}$. Eluent was monitored at $280 \mathrm{~nm}$ and carbohydrate content of each fraction $(200 \mu \mathrm{L})$ was determined according to the phenol-sulphuric acid method [27].

\section{Monosaccharide composition analysis}

The 1-phenyl-3-methyl-5-pyrazolone (PMP) derivatization method [28] was used to analyze monosaccharide composition. Each polysaccharide ( $2 \mathrm{mg}$ ) was hydrolyzed with $2 \mathrm{M}$ trifluoroacetic acid (TFA) at $105^{\circ} \mathrm{C}$ for $3 \mathrm{~h}$. TFA was evaporated by adding methanol under reduced pressure. The hydrolysis product was derivatized with PMP in $0.3 \mathrm{M} \mathrm{NaOH}$ for $1 \mathrm{~h}$ at $70{ }^{\circ} \mathrm{C}$, and then neutralized with $\mathrm{HCl}$. The derivatives were analyzed using a Thermo C18 column $(250 \mathrm{~mm} \times 4.6 \mathrm{~mm})$ coupled to an Agilent HPLC-DAD at $245 \mathrm{~nm}$, at a flow rate of $0.8 \mathrm{~mL} / \mathrm{min}$ of mobile phase: phosphate buffer $(0.1 \mathrm{~mol} / \mathrm{L}, \mathrm{pH} 7.0) /$ $\mathrm{CH}_{3} \mathrm{CN}=83 / 17(\mathrm{v} / \mathrm{v})$. Monosaccharide composition and the molar ratio analysis were carried out by comparing the retention times and peak areas with those of monosaccharide standards.

\section{Mass spectrometric analysis of extracellular proteins}

Proteins precipitated after the $\mathrm{pH}$ adjustment were sent to Shanghai Boyuan Biological Technology CO., LTD (Shanghai, China) for LC-MS/MS analysis. Proteins isolated by two-dimensional (2D) SDS-PAGE were analyzed using an ABI 4800 Plus MALDI TOF/TOF system (Life Technologies). Protein identification was performed using MASCOT 2.3 (http://www.matrixscience.com/, Matrix Science, UK) against the NCBI-Clostridium acetobutylicum database using a significance threshold of $p<0.05$.

\section{Results}

Sporulation and morphological changes of biofilm cells Biofilm formation by $C$. acetobutylicum in fermenters during continuous cultivation was quantified. Accumulation of biofilm was most apparent during day 3 and day 4 . The biofilm could be built up with a maximum dry weight 
of $28 \mathrm{mg} / \mathrm{cm}^{2}$ on the surface of cotton towel (Fig. 1). It was found that during continuous cultivation of C. acetobutylicum biofilm, the cells eventually eliminated sporulation and displayed a vegetative growth. As shown in Fig. 2, swollen clostridial-form cells first appeared at $18 \mathrm{~h}$. These cells are to be the mother cells for spores. With the

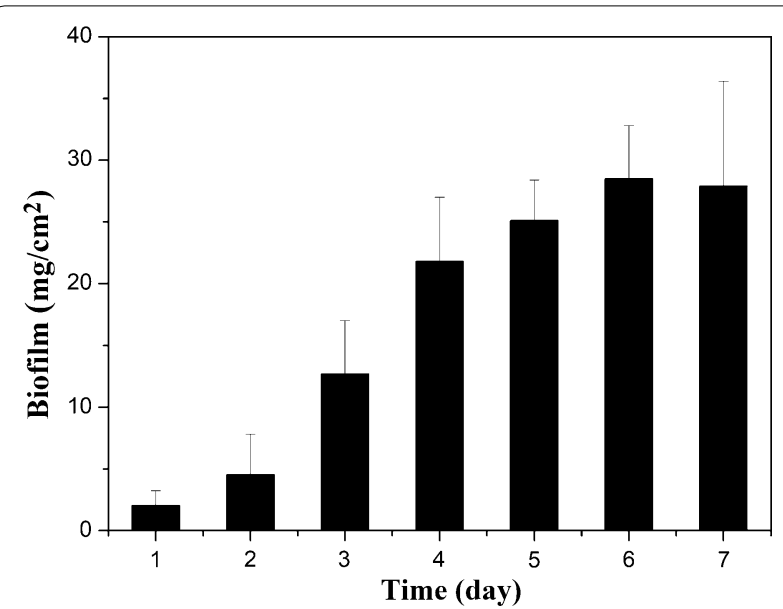

Fig. 1 Amounts of biofilm accumulated on cotton towel over time sporulation, fore spores were formed at $30 \mathrm{~h}$. The final mature spores were released and peaked at $42 \mathrm{~h}$, after which they disappeared rapidly. By $102 \mathrm{~h}$, spores could hardly be observed, leaving almost exclusively vegetative cells. At the same time, the vegetative cells underwent significant morphological changes: from short single cells to long-chain cells. The long chains of cells were observed from $66 \mathrm{~h}$, apparent at $102 \mathrm{~h}$, and predominantly present in the biofilm after $150 \mathrm{~h}$ with a length around $100 \mu \mathrm{m}$.

\section{Decreased expression of sporulation genes in biofilm cells} Inspired by the elimination of sporulation in the biofilm cells during long-term cultivation, expression of sporulation-related genes was investigated. In general, expression of the genes responsible for spore formation was apparently down-regulated in the biofilm over time (Fig. 3). Of the sporulation regulators in C. acetobutylicum, the gene encoding $\sigma^{\mathrm{K}}$ (sigK, CA_C1689) was downregulated over time by eightfold. The most down-regulated genes were those involved in spore coat synthesis (CA_C0613-0614, CA_C1335, CA_C13371338, CA_C2808-2910, CA_C3317), which decreased over time by 6- to 24-fold. An operon CA_C2086-2093 related to stage III sporulation was down-regulated 6to 12 -fold. The small, acid-soluble proteins (SASP) that are used to coat DNA in spores (encoded by CA_C1487
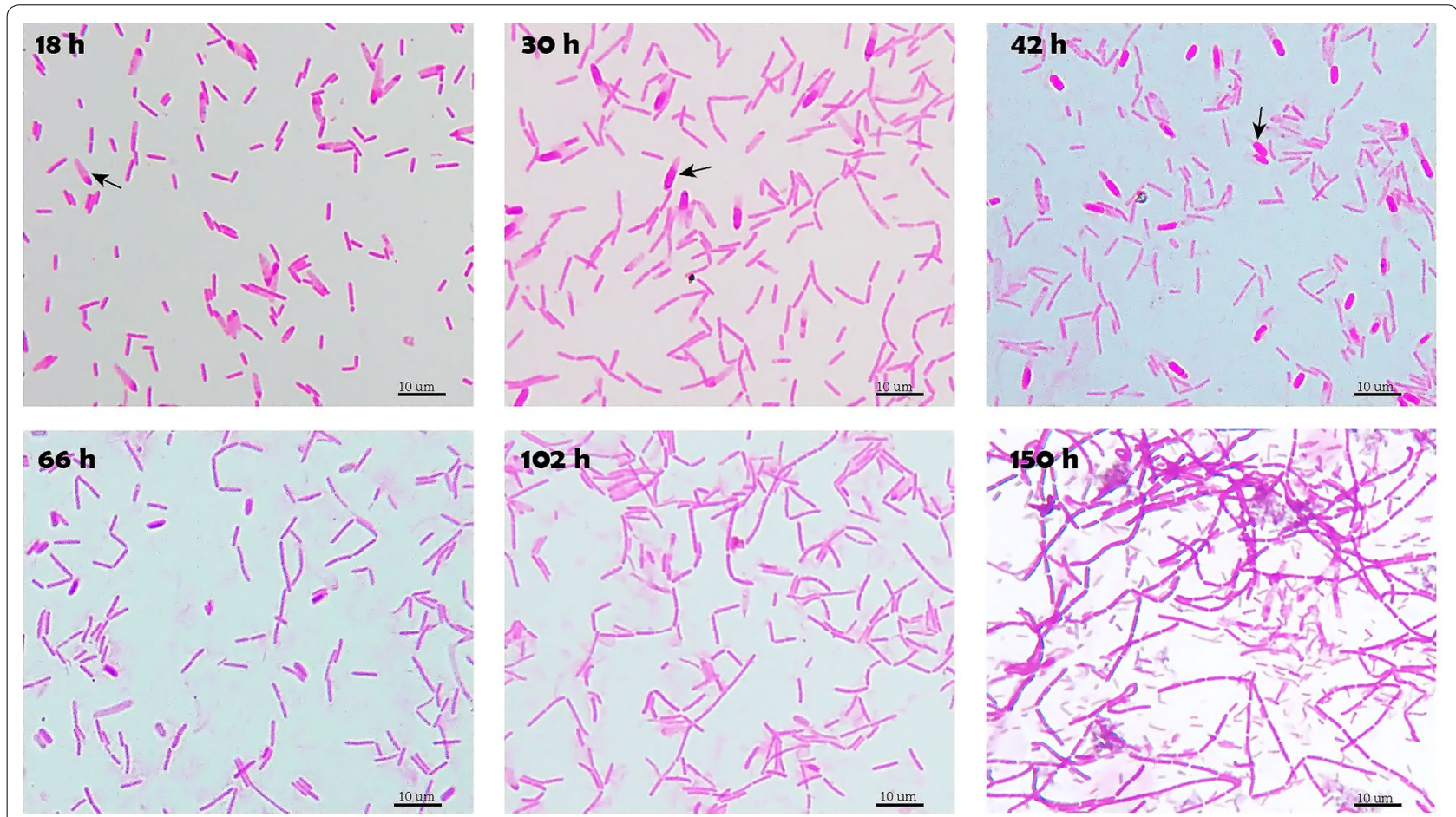

Fig. 2 Elimination of sporulation and vegetative growth of C. acetobutylicum in the biofilm over time. The arrow indicates the clostridial-form cell $(18 \mathrm{~h})$, forespore $(30 \mathrm{~h})$ or free spore $(42 \mathrm{~h})$ 


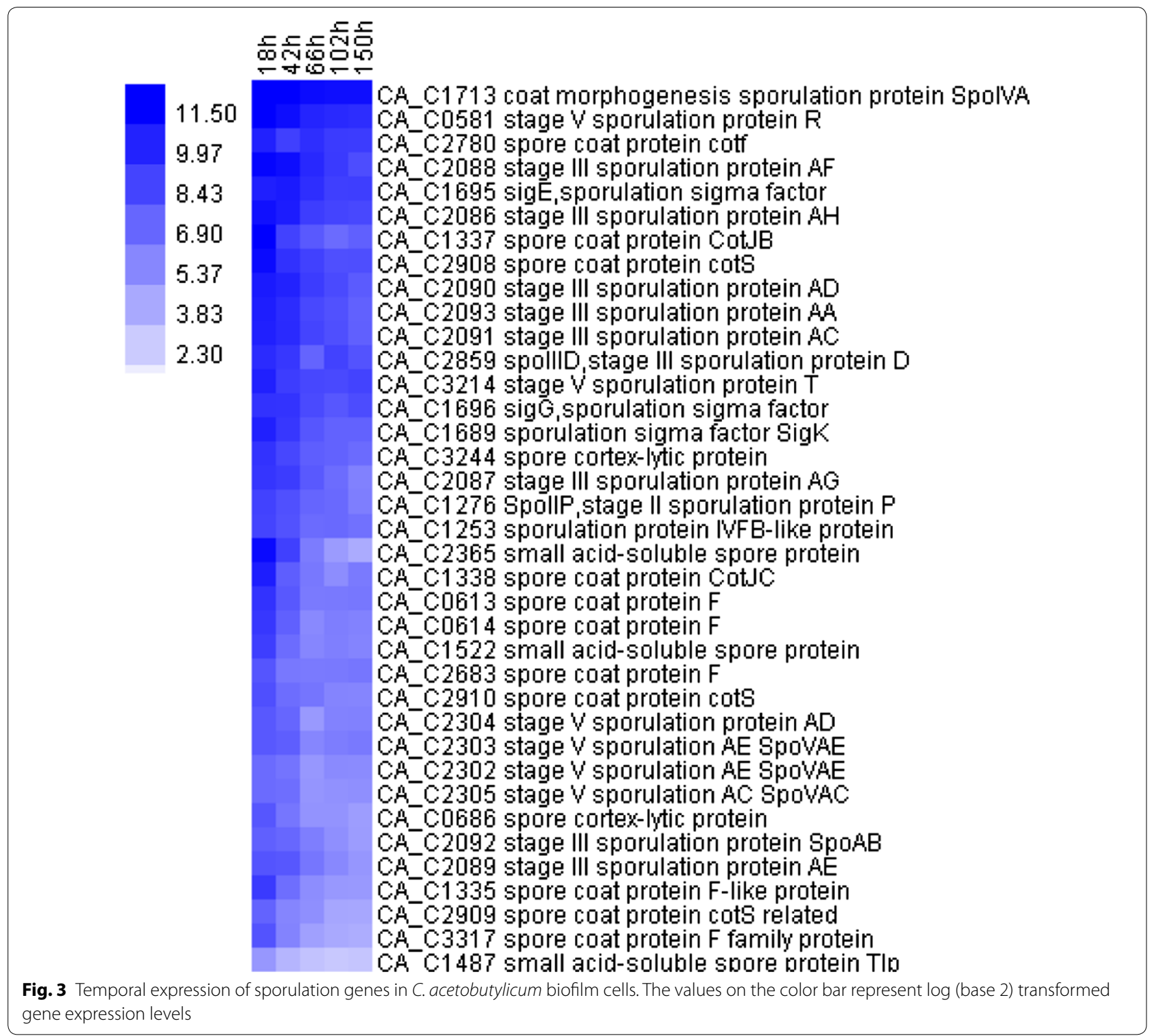

and CA_C1522) were also significantly down-regulated by 48 -fold ( $p<0.01$; Student t test), and the CA_C2365 was down-regulated by 200 -fold. Overall, the decreased expression of sporulation-related genes over time was consistent with the elimination of sporulation in the biofilm.

\section{EPS and wire-like structures in C. acetobutylicum biofilm} EPS and wire-like structures of $C$. acetobutylicum biofilm were observed. As shown in Fig. 4, at the early stage of biofilm development $(4 \mathrm{~h})$, cells were all buried in a gel-like extracellular matrix (as indicated by the blurred area in the image) which was typically excreted by the cells to help adhere onto surfaces. Then it developed into a three-dimensional, high-density cell colony $(16 \mathrm{~h})$. At the edges of the colonies, wire-like structures could be clearly observed. The wires were surprisingly long (could be more than $50 \mu \mathrm{m}$ ) and could be crossconnected. With the development, the wires were eventually imbedded in cells aggregates $(28 \mathrm{~h})$. At the late stage $(40 \mathrm{~h})$, EPS pellicles were also shown. In recent years, a kind of "nanowire" structure has been reported for some bacterial biofilms and was supposed to function in extracellular electron transport [29]. Whether the wire structures observed here are similar to the nanowires and what their roles are in C. acetobutylicum biofilm remain to be investigated. 


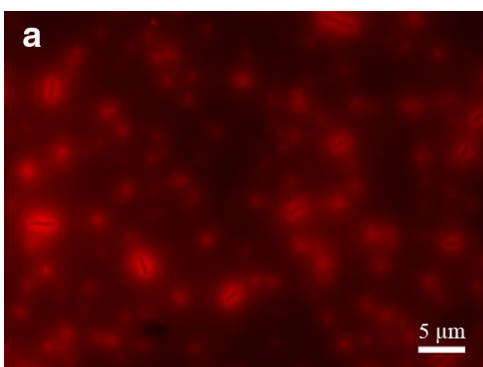

$4 h$

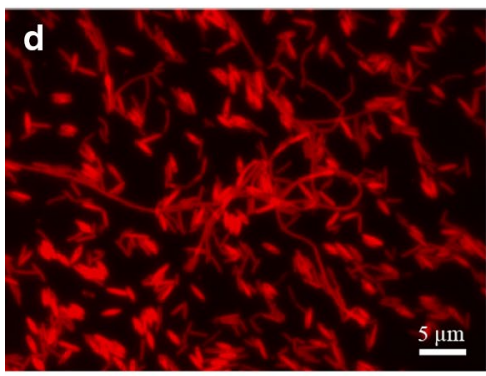

$28 \mathrm{~h}$

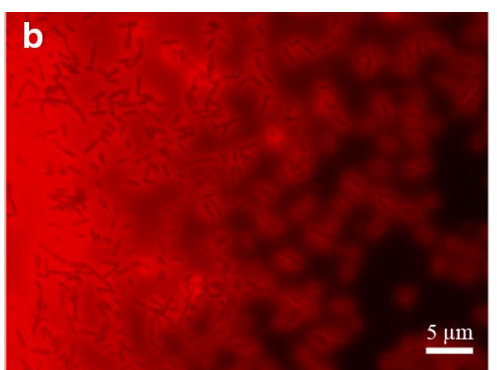

$16 \mathrm{~h}$

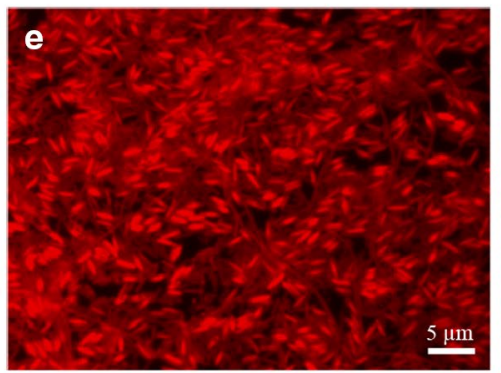

28h

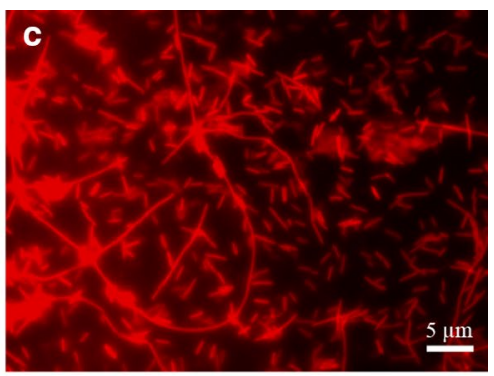

$16 h$

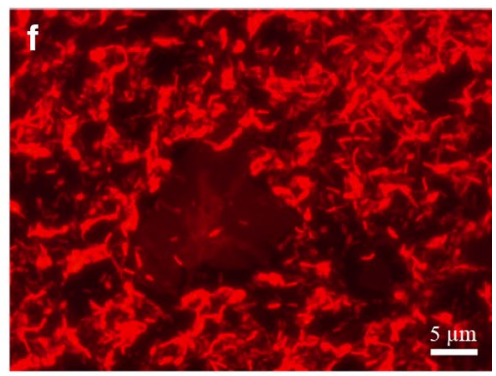

$40 \mathrm{~h}$

Fig. 4 Extracellular polymeric substances and wire-like structures in C. acetobutylicum biofilm. Samples were stained with safranin $\mathrm{O}$ and imaged in a fluorescence microscope. a the early stage of biofilm development; $\mathbf{b}$ high-density cell colonies; $\mathbf{c}$ wire-like structures; $\mathbf{d}$ cellular morphology at the mid stage of biofilm development; $\mathbf{e}$ wires imbedded in cells aggregates; $\mathbf{f}$ EPS pellicles observed in the biofilm

\section{Characterization of C. acetobutylicum biofilm polysaccharides}

After polysaccharides and proteins in C. acetobutylicum biofilm were extracted, the polysaccharides were further isolated by anion exchange chromatography (Fig. 5). Three polysaccharides were obtained which were designated SM1, SM2, and SM3 according to their elution order. A peak at $280 \mathrm{~nm}$ occurred concurrently with each of the polysaccharide peaks, indicating possible presence of polysaccharide-associated proteins. The SM1 comprised the largest fraction $(53 \%, w / w)$ of the polysaccharides, followed by SM2 (26\%, w/w) and SM3 $(21 \%, w / w)$. SM1 was also the most purified polysaccharide as indicated by a much smaller peak at $280 \mathrm{~nm}$ (Fig. 5).

Analysis of monosaccharide composition showed that all the three polysaccharides were heteropolysaccharides with glucose as the primary component (Table 1). SM2 and SM3 were very similar in both of monosaccharide type and molar ratio, consisting of glucose (47-53\%, molar ratio, the same hereinafter), mannose (13-15\%), rhamnose (10-16\%), galactose (9-10\%), aminoglucose (7-9\%), and a little ribose (4-5\%). Compared to SM2 and SM3, the SM1 polysaccharide consisted of more glucose $(58 \%)$, mannose (21\%), and aminoglucose (13\%), but much less rhamnose $(0.8 \%)$, galactose $(0.8 \%)$ and ribose $(0.4 \%)$. SM1 also consisted of unique galacturonic acid
(5.5\%). The presence of uronic acid might explain why the C. acetobutylicum biofilm matrix was alkali soluble.

\section{Identification of $C$. acetobutylicum biofilm proteins}

Proteins extracted from the $C$. acetobutylicum biofilm were identified by LC-MS/MS. The proteins were next ranked according to their emPAI (exponentially modified protein abundance index) which reflects their relative abundance [30]. Table 2 lists the Top 30 abundant proteins of $C$. acetobutylicum biofilm. Strikingly, most of the proteins are commonly known as physiological process related proteins, especially the molecular chaperones and stress proteins. The three most abundant proteins were GroEL, surface layer (S-layer) protein and rubrerythrin, which typically functions as molecular chaperone, structure protein and oxidative stress protein, respectively. Surprisingly, many of the proteins are typically known as intracellular proteins such as the enzymes normally functioning in central metabolism, glyceraldehyde3-phosphate dehydrogenase (GAPDH), triose phosphate isomerase, pyruvate: ferredoxin oxidoreductase, electron transfer flavoprotein and alcohol dehydrogenase. Meanwhile, the biofilm proteins were isolated by $2 \mathrm{D}$ gel electrophoresis and major protein spots were identified by MALDI TOF/TOF mass spectrometry. The major proteins identified on 2D gel were well included in the Top 30 abundant proteins identified by LC-MS/MS, and 

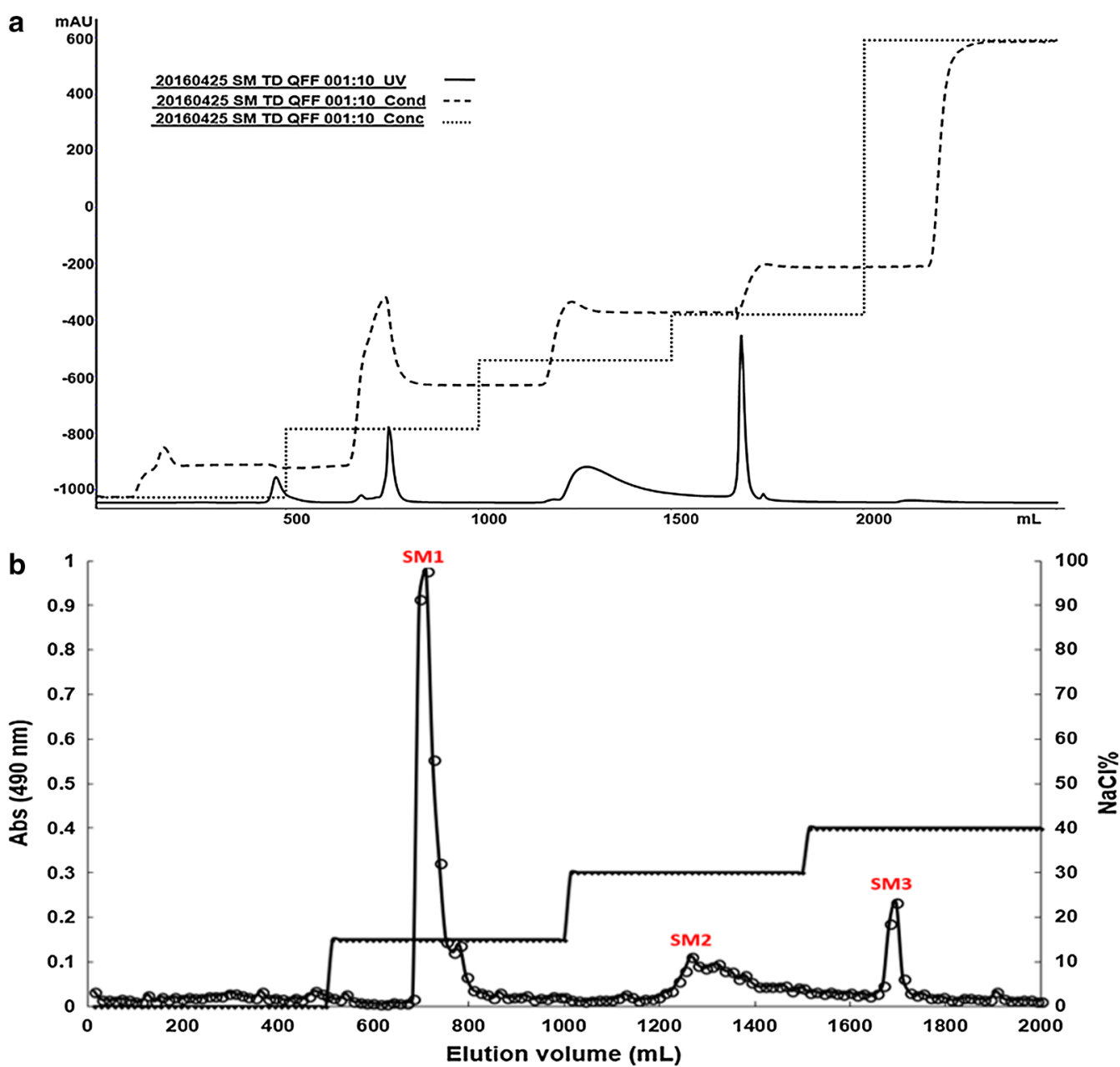

Fig. 5 Isolation of extracellular polysaccharides produced by C. acetobutylicum biofilm on the QFF anion exchange column. a Elution profile monitored at $280 \mathrm{~nm}$; $\mathbf{b}$ the profile of polysaccharides monitored at $492 \mathrm{~nm}$ by the phenol-sulfuric acid method

Table 1 The molar ratio of each monosaccharide in C. acetobutylicum biofilm polysaccharides

\begin{tabular}{lllllllr}
\hline & Glc & Man & GlcN & GalA & Rha & Gal & Rib \\
\hline SM1 & 100 & 36 & 23 & 9.4 & 1.5 & 1.4 & 0.7 \\
SM2 & 100 & 25 & 17 & - & 18 & 20 & 9.0 \\
SM3 & 100 & 32 & 16 & 33 & 20 & 9.6 \\
\hline
\end{tabular}

SM1, SM2 and SM3 are three isolated polysaccharides

Glc glucose, Man mannose, GlcN aminoglucose, GalA galacturonic acid, Rha rhamnose, Gal galactose; Rib ribose

the spots of the three most abundant proteins, GroEL, $S$-layer protein and rubrerythrin were indeed the most distinct protein spots on 2D gel (Fig. 6).

In fact, most of the $C$. acetobutylicum biofilm proteins identified here have been recognized as a kind of nonclassically secreted proteins that do not contain known sequence motifs for secretion or anchoring onto the cell surface [31, 32]. A great number of these proteins have been found to be "moonlight proteins" that have a canonical biochemical function inside the cell and perform a second biochemical function on the cell surface or extracellularly [33, 34]. Table 3 lists the proteins (from the Top 30 abundant proteins list) that have been reported as non-classically secreted proteins or moonlighting proteins. Obviously, many proteins with canonical function in central metabolism, chaperone activity, or 
Table 2 Top 30 extracellular proteins in C. acetobutylicum biofilm identified by LC-MS/MS

\begin{tabular}{|c|c|c|c|c|c|c|c|}
\hline & Gene locus & Score $^{a}$ & Mass $^{\mathbf{b}}$ & Matches $^{c}$ & Sequences $^{d}$ & emPAl $^{e}$ & Description \\
\hline 1 & CA_C2703 & 10,961 & 58,166 & 408 & 29 & 12.3 & Molecular chaperone GroEL (Hsp60) \\
\hline 2 & CEA_G3563 & 3556 & 47,277 & 139 & 17 & 10.3 & Putative S-layer protein \\
\hline 3 & CA_C3597 & 8141 & 20,493 & 187 & 10 & 10.3 & Rubrerythrin \\
\hline 4 & CA_C2710 & 2299 & 28,089 & 71 & 14 & 9.5 & Electron transfer flavoprotein beta-subunit \\
\hline 5 & CA_C0709 & 1619 & 35,999 & 72 & 15 & 8.1 & Glyceraldehyde-3-phosphate dehydrogenase \\
\hline 6 & CA_C2452 & 572 & 15,611 & 24 & 7 & 7.7 & Flavodoxin \\
\hline 7 & CA_C1555 & 2446 & 29,503 & 80 & 10 & 7.5 & Flagellin \\
\hline 8 & CA_C1747 & 556 & 8602 & 21 & 3 & 6.9 & Acyl carrier protein, ACP \\
\hline 9 & CA_C3136 & 5404 & 43,482 & 207 & 18 & 6.8 & Elongation Factor Tu (Ef-Tu) \\
\hline 10 & CA_C2990 & 396 & 7307 & 23 & 2 & 6.2 & Cold shock protein \\
\hline 11 & CA_C1834 & 448 & 9203 & 19 & 4 & 5.9 & Host factor I protein Hfq \\
\hline 12 & CA_C3125 & 299 & 7908 & 7 & 3 & 5.4 & Ribosomal protein L29 \\
\hline 13 & CA_C2712 & 571 & 28,400 & 28 & 10 & 4.9 & Crotonase \\
\hline 14 & CA_C1807 & 182 & 10,251 & 7 & 5 & 4.8 & Ribosomal Protein S15 \\
\hline 15 & CA_C3211 & 1113 & 10,341 & 59 & 6 & 4.7 & DNA binding protein HU \\
\hline 16 & CA_P0164 & 1098 & 23,666 & 33 & 8 & 4.6 & Acetoacetyl-CoA:acetate/butyrate CoA-transferase subunit B \\
\hline 17 & CA_C2704 & 745 & 10,420 & 27 & 5 & 4.6 & Molecular chaperone groES (Hsp10, Hsp60 cofactor) \\
\hline 18 & CA_C3145 & 553 & 12,670 & 24 & 5 & 4.4 & Ribosomal protein L7/L12 \\
\hline 19 & CA_C3076 & 627 & 32,321 & 30 & 12 & 4.3 & Phosphate butyryltransferase \\
\hline 20 & CA_C1281 & 757 & 17,734 & 29 & 7 & 3.8 & Heat shock protein grpE (hsp20, Hsp70 cofactor) \\
\hline 21 & CA_C1282 & 2280 & 65,723 & 77 & 24 & 3.8 & Molecular chaperone DnaK (Hsp70) \\
\hline 22 & CA_C2229 & 4951 & 129,740 & 191 & 43 & 3.7 & Pyruvate:ferredoxin oxidoreductase \\
\hline 23 & CA_C2641 & 782 & 49,565 & 37 & 19 & 3.7 & FKBP-type peptidyl-prolyl cis-transisomerase (trigger factor) \\
\hline 24 & CA_C3075 & 744 & 39,146 & 33 & 15 & 3.7 & Butyrate kinase, BUK \\
\hline 25 & CA_C2873 & 1247 & 41,443 & 53 & 16 & 3.7 & Acetyl coenzyme A acetyltransferase (thiolase) \\
\hline 26 & CA_P0165 & 725 & 23,797 & 22 & 8 & 3.3 & Acetoacetate decarboxylase \\
\hline 27 & CA_P0162 & 3768 & 95,774 & 175 & 32 & 3.2 & Alcohol dehydrogenase E \\
\hline 28 & CA_C0711 & 452 & 26,698 & 17 & 11 & 3.1 & Triosephosphate isomerase \\
\hline 29 & CA_C2597 & 461 & 17,599 & 19 & 5 & 3.1 & Hypothetical protein \\
\hline 30 & CA_C3558 & 1128 & 48,599 & 51 & 10 & 3.0 & Probable S-layer protein \\
\hline
\end{tabular}

a All scores were statistically significant $(p<0.05$; Student $t$ test). Higher score means higher probability

b Theoretical molecular mass

c The number of peptides that matched the identified protein with $p<0.05$

$d$ The number of distinct (nonredundant) peptides that matched the identified protein with $p<0.05$ (Student $t$ test)

e Exponentially modified Protein Abundance Index

protein synthesis and nucleic acid stability could moonlight as bacterial adhesins and interact with the environment. While these proteins were abundant in the biofilm, no apparent regulation of their gene transcription was observed (Additional file 2: Sheet 3).

\section{Discussion}

C. acetobutylicum has attracted considerable interest due to its unique capability of biosynthesizing a range of liquid fuels and bulk chemicals that are fundamentally important to human society. It has been long accepted that sporulating clostridial form of C. acetobutylicum cells is the solvent-forming phenotype, that is, solventogenesis is coupled to sporulation. However, Tracy and his co-workers observed a stronger correlation between solvent production and the vegetative cell type than the clostridial-form type based on flow cytometry assisted cell-sorting techniques. They also demonstrated that a sigF mutant blocked sporulation but still produced comparable solvent in batch fermentation [71, 72]. Despite this, the view that solventogenesis is coupled to sporulation is still prevailing in the field $[73,74]$. Here, our results clearly showed that $C$. acetobutylicum could eliminate sporulation and display vegetative growth in biofilm over time. In this way, instead of being impaired, the solvent production was greatly improved [12, 22]. 


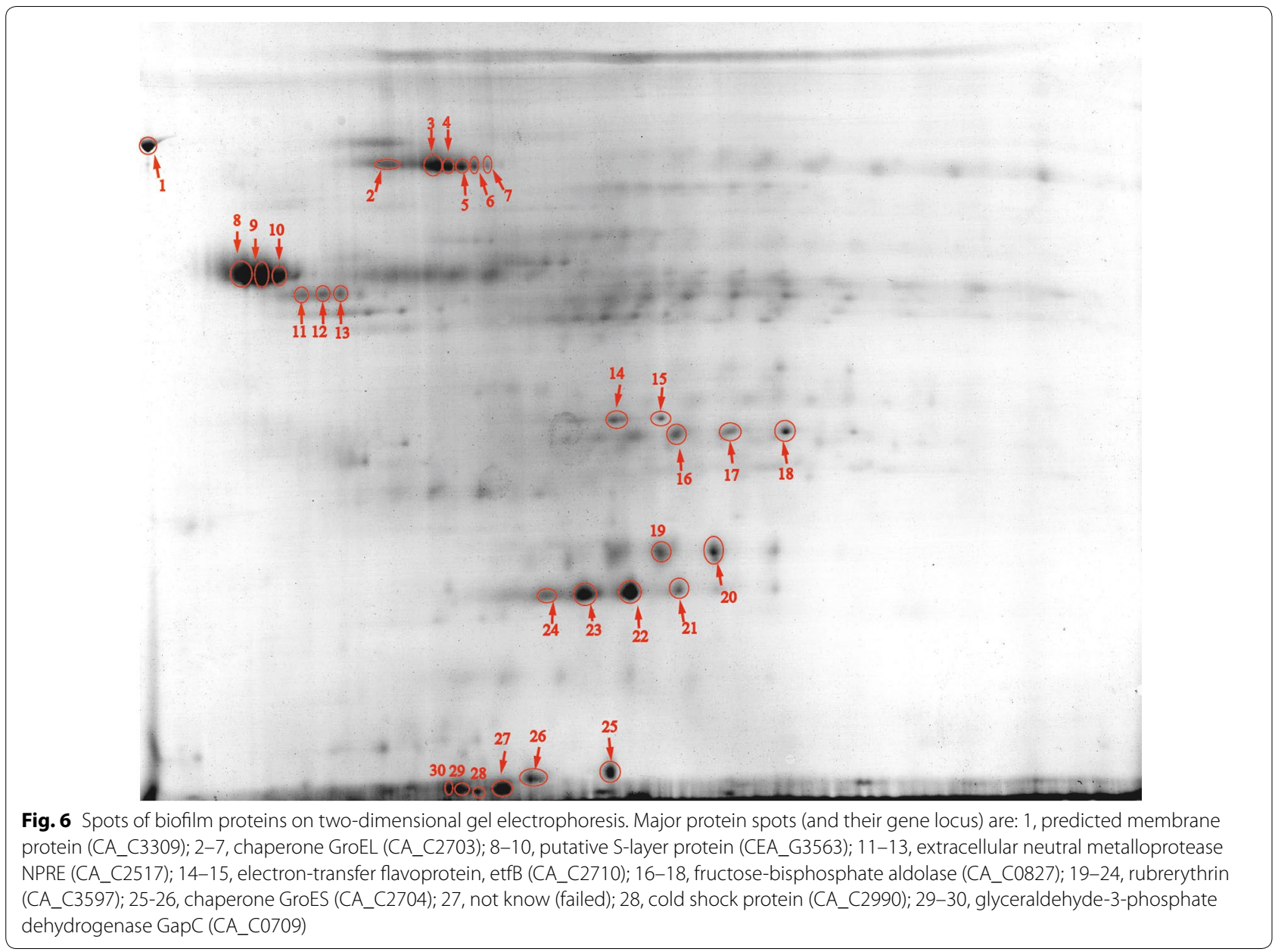

Therefore, it is plausible that sporulation and solventogenesis can be uncoupled in C. acetobutylicum. This is of particular importance, because it would encourage researchers to develop long-term continuous cultivation processes. Besides elimination of sporulation, $C$. acetobutylicum biofilm cells also exhibited significant morphological changes. The prolonged chain-like morphology observed for C. acetobutylicum biofilm cells was also observed for Bacillus subtilis biofilm cells. In B. subtilis, a transcriptional regulator SinR represses the genes responsible for EPS production and promotes cell separation and motility. During biofilm development, SinR activity is antagonized. Low SinR activity results in EPS production and loss of cell motility. Thus, motile single cells switch to long chains of nonmotile cells [75]. Considering the presence of $\operatorname{SinR}$ in C. acetobutylicum, this is probably also the case in C. acetobutylicum.

Despite the fact that $C$. acetobutylicum biofilm has been extensively exploited for producing industrial products $[4,12,16,21]$, the biosynthetic process and molecular composition of $C$. acetobutylicum biofilm remain completely unknown. Here, for the first time isolated polysaccharides and proteins from $C$. acetobutylicum biofilm were reported. C. acetobutylicum biofilm contained three polysaccharides which were all heteropolysaccharides. Recently, a polysaccharide separated from C. acetobutylicum culture supernatant was reported [76]. Consistent with our results, the supernatant polysaccharide was also a heteropolysaccharide and its monosaccharide composition seemed similar to those of the SM2 and SM3. While the supernatant polysaccharide was characterized with glucose (34\%, molar ratio), rhamnose (40\%), mannose $(13 \%)$ and galactose $(10 \%)$ as its primary monosaccharides, the SM2 and SM3 characterized here also consisted of glucose (47-53\%), rhamnose (10-16\%), mannose $(13-21 \%)$ and galactose $(9-10 \%)$ as their primary monosaccharides (Table 1), although the monosaccharide ratio differed. However, the polysaccharide SM1 that represented the major polysaccharide in C. acetobutylicum biofilm had a more distinct composition: it contained predominantly glucose $(58 \%)$, mannose $(21 \%)$, and aminoglucose (13\%). Altogether, it seemed that $C$. 
Table 3 Major C. acetobutylicum biofilm proteins that have been reported as non-classically secreted proteins with potential moonlighting functions

\begin{tabular}{|c|c|}
\hline Intracellular function & Moonlighting function \\
\hline \multicolumn{2}{|l|}{ Chaperones } \\
\hline Molecular chaperone groel & Adhesin $[33,35-37]$; bind mucin, invertase and fibronectin $[38,39]$ \\
\hline Molecular chaperone dnak & Bind plasminogen and invertase [40-42] \\
\hline Heat shock protein grpe & Not characterized $[32,39,43]$ \\
\hline Molecular chaperone groes & Not characterized $[32,43]$ \\
\hline Cold shock protein & Not characterized $[44,45]$ \\
\hline \multicolumn{2}{|l|}{ Protein synthesis and nucleic acid stability } \\
\hline Elongation factor Tu (Ef-Tu) & Attach to human cells, bind fibronectin and plasminogen [46-49] \\
\hline Trigger factor & Not characterized $[43,44,50,51]$ \\
\hline Ribosomal protein L29 & Not characterized $[43,45,51]$ \\
\hline Ribosomal protein S15 & Not characterized $[52,53]$ \\
\hline Ribosomal protein $L 7 / L 12$ & Not characterized $[52,54]$ \\
\hline \multicolumn{2}{|l|}{ Central metabolism } \\
\hline Glyceraldehyde-3-phosphate dehydrogenase (GAPDH) & Adhesin [55-57]; bind plasminogen, collagen, fibronectin and RNA $[34,58,59]$ \\
\hline Triosephosphate isomerase & Adhesin $[33,60]$; bind plasminogen, laminin and fibronectin $[61,62]$ \\
\hline Alcohol dehydrogenase & Bind plasminogen $[63,64]$ \\
\hline Pyruvate: ferredoxin oxidoreductase & Adhesin $[65,66]$ \\
\hline Electron transfer flavoprotein beta-subunit & Not characterized $[44,50,54]$ \\
\hline Acetyl coenzyme A acetyltransferase (thiolase) & Not characterized $[44,67]$ \\
\hline Rubrerythrin & Not characterized $[52,68]$ \\
\hline Acyl carrier protein, $\mathrm{ACP}$ & Not characterized $[69,70]$ \\
\hline
\end{tabular}

acetobutylicum liked to produce a variety of heteropolysaccharides varying in monosaccharide composition. In addition, the biofilm polysaccharides, especially the SM1, proved hard to re-dissolve after lyophilization. Also, they were possibly associated with some non-carbohydrate substances. Despite our try of various protein removal methods, they still defied ${ }^{1} \mathrm{H}-\mathrm{NMR}$ analysis.

Strikingly, a great variety of proteins were found abundantly present in C. acetobutylicum biofilm. One of the most abundant proteins was a protein annotated as putative S-layer protein (Table 2; Fig. 6). The gene encoding this protein is designated CEA_G3563 in C. acetobutylicum EA2018 and SMB_G3598 in C. acetobutylicum DSM 1731. In both strains, it is located in an operon together with and downstream of an S-layer protein encoding gene [77]. It shows $81 \%$ sequence identity to a S-layer protein from C. felsineum DSM 794 (Sequence ID: WP_077894211), but both have been poorly studied. S-layers are crystalline monomolecular assemblies of protein or glycoprotein, which represent one of the most common cell envelope structures in bacteria [78]. In Clostridium difficile, S-layer proteins were demonstrated essential for biofilm formation perhaps due to the fact that S-layer is essential for anchoring cell wall associated proteins that are required for adhesion during biofilm formation [79]. Studies also showed that S-layer was required for normal growth in $C$. difficile [80, 81], while a non-matured S-layer protein induced the apparition of a bigger biofilm [82]. Except the putative S-layer protein, most of the $C$. acetobutylicum proteins were typically intracellular proteins (Tables 2, 3). It has previously been reported that a variety of Gram-positive bacteria, such as $S$. aureus and B. subtilis, release intracellular proteins into the external environment during stationary phase $[83,84]$. These proteins are considered to be secreted in a non-classical pathway and some of them (e.g., the GroEL) have been extensively found to moonlight as adhesins and contribute to the biofilm formation [32, 33, 84]. For instance, it was shown that deletion of GroEL-phosphorylating PrkC in Bacillus anthracis abrogated biofilm formation, while overexpression of GroEL led to increased biofilm formation $[85,86]$. Another intracellular protein abundant in the biofilm is a rubrerythrin encoded by rbr3B (CA_C3597). In this rubrerythrin, the order of the two functional domains is reversed compared to normal rubrerythrins [87]. Although this rubrerythrin has been demonstrated to be involved in $\mathrm{H}_{2} \mathrm{O}_{2}$ and $\mathrm{O}_{2}$ detoxification, its role in biofilm remains to be studied.

Besides the non-classical secretion, the abundance of intracellular proteins could also be a result of cell lysis inside the biofilm during long-term development. While a biofilm could persistently exist, a subpopulation of the 
cells inside is likely lysed due to various mechanisms [88]. The biofilm matrix could act as a recycling center by keeping the components of lysed cells available $[19,88]$. A biofilm-forming mechanism was recently proposed using Staphylococcus aureus or Pseudomonas aeruginosa biofilm as a model $[83,89]$. In these models, cytoplasmic proteins that were released from cells or cell lysate proteins could associate with the cell surface in response to decreasing $\mathrm{pH}$ during biofilm formation. Considering the presence of abundant cytoplasmic proteins in the $C$. acetobutylicum biofilm as well as a low $\mathrm{pH}$ level (usually around $\mathrm{pH}$ 4.2) during C. acetobutylicum fermentation, this mechanism also be plausible for C. acetobutylicum biofilm.

\section{Conclusions}

Clostridium acetobutylicum biofilm cells eliminated sporulation and performed vegetative growth over time, indicating that vegetative $C$. acetobutylicum cells rather than the spore-forming cells were the solvent-forming cells. EPS and wire-like structures were observed. The biofilm contained three heteropolysaccharides. The major fraction consisted of predominantly glucose, mannose and aminoglucose. A variety of proteins including nonclassically secreted proteins were present in the biofilm, with GroEL, a S-layer protein and rubrerythrin being the most abundant. Of these proteins, many proteins such as GroEL, Ef-Tu and glyceraldehyde-3-phosphate dehydrogenase could moonlight as adhesins which might contribute to the biofilm formation. This study provides important insights into C. acetobutylicum biofilm. Future studies should genetically manipulate the main components to elucidate their specific roles in C. acetobutylicum biofilm.

\section{Additional files}

Additional file 1. Evaluation of different extraction methods and ${ }^{1} \mathrm{H}-\mathrm{NMR}$ spectra of polysaccharides.

Additional file 2. Full list of the biofilm proteins and relevant gene expression data.

\section{Abbreviations}

2D: two-dimensional; EPS: extracellular polymeric substances; LC-MS/MS: liquid chromatography coupled with tandem mass spectrometry; MALDI TOF/ TOF: matrix-assisted laser desorption/ionization time-of-flight/time-of-flight mass spectrometer; PMP: 1-phenyl-3-methyl-5-pyrazolone; QFF: q-sepharose fast flow chromatography column; SDS-PAGE: sodium dodecyl sulfate-polyacrylamide gel electrophoresis.

\section{Authors' contributions}

$\mathrm{DL}$ and $\mathrm{HY}$ designed experiments. DL and ZY performed experiments. WZ, YC, $\mathrm{HN}$, and JW contributed materials and sample analysis. DL and ZY analyzed data. DL and HY wrote the manuscript. All authors read and approved the final manuscript.

\section{Author details}

${ }^{1}$ State Key Laboratory of Materials-Oriented Chemical Engineering, College of Biotechnology and Pharmaceutical Engineering, Nanjing Tech University, No. 30, Puzhu South Road, Nanjing 211800, China. ${ }^{2}$ Jiangsu National Synergetic Innovation Center for Advance Material (SICAM), No. 30, Puzhu South Road, Nanjing 211800, China.

\section{Acknowledgements}

We thank Dr. Xia Zhao from Qingdao Haiyang University (Shandong, China) for the help with analysis of polysaccharides.

\section{Competing interests}

The authors declare that they have no competing interests.

\section{Availability of data and materials}

The raw transcriptomic data were uploaded to the Gene Expression Omnibus (GEO) database under Accession Number GSE72765. All other datasets supporting the conclusions of this article are included within the article.

\section{Consent for publication}

Not applicable.

Ethics approval and consent to participate

Not applicable.

\section{Funding}

This work was supported by the Jiangsu Provincial Natural Science Foundation of China (Grant No.: BK20150938); the National Nature Science Foundation of China (Grant No.: 21706123); the Major Research Plan of the National Natural Science Foundation of China (21390204); the key program of the National Natural Science Foundation of China (21636003); the Program for Changjiang Scholars and Innovative Research Team in University (IRT_14R28); the Priority Academic Program Development of Jiangsu Higher Education Institutions (PAPD), and the Jiangsu Synergetic Innovation Center for Advanced Bio-Manufacture.

\section{Publisher's Note}

Springer Nature remains neutral with regard to jurisdictional claims in published maps and institutional affiliations.

Received: 21 July 2018 Accepted: 13 November 2018

Published online: 20 November 2018

References

1. Flemming H-C, Wingender J, Szewzyk U, Steinberg P, Rice SA, Kjelleberg S. Biofilms: an emergent form of bacterial life. Nat Rev Microbiol. 2016;14:563.

2. Morikawa M. Beneficial biofilm formation by industrial bacteria Bacillus subtilis and related species. J Biosci Bioeng. 2006;101:1-8.

3. Dolejš I, Rebroš M, Rosenberg M. Immobilisation of Clostridium spp. for production of solvents and organic acids. Chem Pap. 2014;68:1-14.

4. Qureshi N, Schripsema J, Lienhardt J, Blaschek H. Continuous solvent production by Clostridium beijerinckii BA101 immobilized by adsorption onto brick. World J Microbiol Biotechnol. 2000;16:377-82.

5. Pratt LA, Kolter R. Genetic analyses of bacterial biofilm formation. Curr Opin Microbiol. 1999;2:598-603.

6. Weinberg E. Suppression of bacterial biofilm formation by iron limitation. Med Hypotheses. 2004;63:863-5.

7. Dewanti R, Wong AC. Influence of culture conditions on biofilm formation by Escherichia coli O157: H7. Int J Food Microbiol. 1995;26:147-64.

8. Speranza B, Corbo MR, Sinigaglia M. Effects of nutritional and environmental conditions on Salmonella sp. biofilm formation. J Food Sci. 2011;76:M12-6.

9. Miqueleto A, Dolosic C, Pozzi E, Foresti E, Zaiat M. Influence of carbon sources and $\mathrm{C} / \mathrm{N}$ ratio on EPS production in anaerobic sequencing 
batch biofilm reactors for wastewater treatment. Bioresour Technol. 2010;101:1324-30.

10. Berlanga $M$, Guerrero R. Living together in biofilms: the microbial cell factory and its biotechnological implications. Microb Cell Fact. 2016;15:165.

11. Liu D, Yang Z, Wang P, Niu H, Zhuang W, Chen Y, Wu J, Zhu C, Ying H, Ouyang P. Towards acetone-uncoupled biofuels production in solventogenic Clostridium through reducing power conservation. Metab Eng. 2018:47:102-12.

12. Liu D, Chen Y, Li A, Ding F, Zhou T, He Y, Li B, Niu H, Lin X, Xie J. Enhanced butanol production by modulation of electron flow in Clostridium acetobutylicum B3 immobilized by surface adsorption. Biores Technol. 2013;129:321-8.

13. Survase $S A$, van Heiningen A, Granström T. Continuous bio-catalytic conversion of sugar mixture to acetone-butanol-ethanol by immobilized Clostridium acetobutylicum DSM 792. Appl Microbiol Biotechnol. 2012;93:2309-16.

14. Chen Y, Zhou T, Liu D, Li A, Xu S, Liu Q, Li B, Ying H. Production of butanol from glucose and xylose with immobilized cells of Clostridium acetobutylicum. Biotechnol Bioprocess Eng. 2013;18:234-41.

15. Liu D, Chen Y, Ding F-Y, Zhao T, Wu J-L, Guo T, Ren H-F, Li B-B, Niu H-Q, Cao Z. Biobutanol production in a Clostridium acetobutylicum biofilm reactor integrated with simultaneous product recovery by adsorption. Biotechnol Biofuels. 2014;7:5.

16. Huang W-C, Ramey DE, Yang S-T: Continuous production of butanol by Clostridium acetobutylicum immobilized in a fibrous bed bioreactor. In: proceedings of the twenty-fifth symposium on biotechnology for fuels and chemicals held May 4-7, 2003, in Breckenridge, CO. Berlin: Springer; 2004. p. 887-98.

17. Mah T-FC, O'toole GA. Mechanisms of biofilm resistance to antimicrobial agents. Trends Microbiol. 2001:9:34-9.

18. Harrison JJ, Ceri H, Turner RJ. Multimetal resistance and tolerance in microbial biofilms. Nat Rev Microbiol. 2007;5:928.

19. Flemming $\mathrm{H}-\mathrm{C}$, Wingender J. The biofilm matrix. Nat Rev Microbiol. 2010;8:623.

20. Wang Z-W, Chen S. Potential of biofilm-based biofuel production. Appl Microbiol Biotechnol. 2009;83:1-18.

21. Pantaléon V, Bouttier S, Soavelomandroso AP, Janoir C, Candela T. Biofilms of Clostridium species. Anaerobe. 2014;30:193-8.

22. Liu D, Xu J, Wang Y, Chen Y, Shen X, Niu H, Guo T, Ying H. Comparative transcriptomic analysis of Clostridium acetobutylicum biofilm and planktonic cells. J Biotechnol. 2016;218:1-12.

23. Zhuang W, Yang J, Wu J, Liu D, Zhou J, Chen Y, Ying H. Extracellular polymer substances and the heterogeneity of Clostridium acetobutylicum biofilm induced tolerance to acetic acid and butanol. RSC Adv. 2016;6:33695-704.

24. Yu Z, Li J, Zhu J, Zhu M, Jiang F, Zhang J, Li Z, Zhong M, Kaye JB, Du J. A synthetic transmembrane segment derived from TRPV 4 channel selfassembles into potassium-like channels to regulate vascular smooth muscle cell membrane potential. J Mater Chem B. 2014;2:3809-18.

25. Yamamoto D, Uchida J. Rapid nuclear staining of Rhizoctonia solani and related fungi with acridine orange and with safranin O. Mycologia. $1982 \cdot 74 \cdot 145-9$

26. Sun $M, L i W-W, Y u H-Q$, Harada H. A novel integrated approach to quantitatively evaluate the efficiency of extracellular polymeric substances (EPS) extraction process. Appl Microbiol Biotechnol. 2012;96:1577-85.

27. Liu D, Chen Y, Li A, Xie J, Xiong J, Bai J, Chen X, Niu H, Zhou T, Ying H. Enhanced uridine $5^{\prime}$-monophosphate production by whole cell of Saccharomyces cerevisiae through rational redistribution of metabolic flux. Bioprocess Biosyst Eng. 2012;35:729-37.

28. Li H, Gao T, Wang J, Tian S, Yuan X, Zhu H. Structural identification and antitumor activity of the extracellular polysaccharide from Aspergillus terreus. Process Biochem. 2016:51:1714-20.

29. Pirbadian S, Barchinger SE, Leung KM, Byun HS, Jangir Y, Bouhenni RA, Reed SB, Romine MF, Saffarini DA, Shi L. Shewanella oneidensis MR-1 nanowires are outer membrane and periplasmic extensions of the extracellular electron transport components. Proc Natl Acad Sci. 2014;111:12883-8.

30. Ishihama Y, Oda Y, Tabata T, Sato T, Nagasu T, Rappsilber J, Mann M. Exponentially modified protein abundance index (emPAl) for estimation of absolute protein amount in proteomics by the number of sequenced peptides per protein. Mol Cell Proteomics. 2005;4:1265-72.

31. Bendtsen JD, Jensen LJ, Blom N, Von Heijne G, Brunak S. Feature-based prediction of non-classical and leaderless protein secretion. Protein Eng Des Sel. 2004;17:349-56.

32. Wang G, Xia Y, Song X, Ai L. Common non-classically secreted bacterial proteins with experimental evidence. Curr Microbiol. 2016;72:102-11.

33. Amblee V, Jeffery CJ. Physical features of intracellular proteins that moonlight on the cell surface. PLOS ONE. 2015;10:e0130575.

34. Kainulainen V, Korhonen TK. Dancing to another tune-adhesive moonlighting proteins in bacteria. Biology. 2014;3:178-204.

35. Hennequin C, Porcheray F, Waligora-Dupriet A-J, Collignon A, Barc M-C, Bourlioux P, Karjalainen T. GroEL (Hsp60) of Clostridium difficile is involved in cell adherence. Microbiology. 2001;147:87-96.

36. Wampler JL, Kim K-P, Jaradat Z, Bhunia AK. Heat shock protein 60 acts as a receptor for the Listeria adhesion protein in Caco-2 cells. Infect Immun. 2004;72:931-6.

37. Arai T, Ochiai K, Senpuku H. Actinomyces naeslundii GroEL-dependent initial attachment and biofilm formation in a flow cell system. J Microbiol Methods. 2015;109:160-6.

38. Bergonzelli GE, Granato D, Pridmore RD, Marvin-Guy LF, Donnicola D, Corthésy-Theulaz IE. GroEL of Lactobacillus johnsonii La1 (NCC 533) is cell surface associated: potential role in interactions with the host and the gastric pathogen Helicobacter pylori. Infect Immun. 2006;74:425-34.

39. Katakura Y, Sano R, Hashimoto T, Ninomiya K, Shioya S. Lactic acid bacteria display on the cell surface cytosolic proteins that recognize yeast mannan. Appl Microbiol Biotechnol. 2010;86:319-26.

40. Candela M, Centanni M, Fiori J, Biagi E, Turroni S, Orrico C, Bergmann S, Hammerschmidt S, Brigidi P. DnaK from Bifidobacterium animalis subsp. lactis is a surface-exposed human plasminogen receptor upregulated in response to bile salts. Microbiology. 2010;156:1609-18.

41. Hagemann L, Gründel A, Jacobs E, Dumke R. The surface-displayed chaperones GroEL and DnaK of Mycoplasma pneumoniae interact with human plasminogen and components of the extracellular matrix. Pathog Dis. 2017:75:1. https://doi.org/10.1093/femspd/ftx017.

42. Xolalpa W, Vallecillo AJ, Lara M, Mendoza-Hernandez G, Comini M, Spallek $R$, Singh M, Espitia C. Identification of novel bacterial plasminogenbinding proteins in the human pathogen Mycobacterium tuberculosis. Proteomics. 2007;7:3332-41.

43. Beck HC, Madsen SM, Glenting J, Petersen J, Israelsen H, Nørrelykke MR, Antonsson M, Hansen AM. Proteomic analysis of cell surface-associated proteins from probiotic Lactobacillus plantarum. FEMS Microbiol Lett. 2009;297:61-6

44. Gohar M, Gilois N, Graveline R, Garreau C, Sanchis V, Lereclus D. A comparative study of Bacillus cereus, Bacillus thuringiensis and Bacillus anthracis extracellular proteomes. Proteomics. 2005;5:3696-711.

45. Xia XX, Han MJ, Lee SY, Yoo JS. Comparison of the extracellular proteomes of Escherichia coli B and K-12 strains during high cell density cultivation. Proteomics. 2008:8:2089-103.

46. Zhang Y, Xiang X, Lu Q, Zhang L, Ma F, Wang L. Adhesions of extracellular surface-layer associated proteins in Lactobacillus M5-L and Q8-L. J Dairy Sci. 2016;99:1011-8.

47. Granato D, Bergonzelli GE, Pridmore RD, Marvin L, Rouvet M, CorthésyTheulaz IE. Cell surface-associated elongation factor Tu mediates the attachment of Lactobacillus johnsonii NCC533 (La1) to human intestinal cells and mucins. Infect Immun. 2004;72:2160-9.

48. Widjaja M, Harvey KL, Hagemann L, Berry IJ, Jarocki VM, Raymond BBA, Tacchi JL, Gründel A, Steele JR, Padula MP. Elongation factor Tu is a multifunctional and processed moonlighting protein. Scientific reports. 2017:7:11227.

49. Kunert A, Losse J, Gruszin C, Hühn M, Kaendler K, Mikkat S, Volke D, Hoffmann R, Jokiranta TS, Seeberger H. Immune evasion of the human pathogen Pseudomonas aeruginosa: elongation factor Tuf is a factor $\mathrm{H}$ and plasminogen binding protein. J Immunol. 2007;179:2979-88.

50. Chitlaru T, Gat O, Gozlan Y, Ariel N, Shafferman A. Differential proteomic analysis of the Bacillus anthracis secretome: distinct plasmid and chromosome $\mathrm{CO}_{2}$-dependent cross talk mechanisms modulate extracellular proteolytic activities. J Bacteriol. 2006;188:3551-71.

51. Voigt B, Schweder T, Sibbald MJ, Albrecht D, Ehrenreich A, Bernhardt J, Feesche J, Maurer KH, Gottschalk G, van Dijl JM. The extracellular 
proteome of Bacillus licheniformis grown in different media and under different nutrient starvation conditions. Proteomics. 2006;6:268-81.

52. Mao S, Luo Y, Bao G, Zhang Y, Li Y, Ma Y. Comparative analysis on the membrane proteome of Clostridium acetobutylicum wild type strain and its butanol-tolerant mutant. Mol BioSyst. 2011;7:1660-77.

53. Thein M, Sauer G, Paramasivam N, Grin I, Linke D. Efficient subfractionation of gram-negative bacteria for proteomics studies. J Proteome Res. 2010;9:6135-47.

54. Bittel M, Gastiger S, Amin B, Hofmann J, Burkovski A. Surface and extracellular proteome of the emerging pathogen Corynebacterium ulcerans. Proteomes. 2018;6:18.

55. Tunio SA, Oldfield NJ, Ala'Aldeen DA, Wooldridge KG, Turner DP. The role of glyceraldehyde 3-phosphate dehydrogenase (GapA-1) in Neisseria meningitidis adherence to human cells. BMC Microbiol. 2010;10:280.

56. Bergmann S, Rohde M, Hammerschmidt S. Glyceraldehyde-3-phosphate dehydrogenase of Streptococcus pneumoniae is a surface-displayed plasminogen-binding protein. Infect Immun. 2004;72:2416-9.

57. Zhu W, Zhang Q, Li J, Wei Y, Cai C, Liu L, Xu Z, Jin M. Glyceraldehyde3-phosphate dehydrogenase acts as an adhesin in Erysipelothrix rhusiopathiae adhesion to porcine endothelial cells and as a receptor in recruitment of host fibronectin and plasminogen. Vet Res. 2017;48:16.

58. Barbosa MS, Báo SN, Andreotti PF, de Faria FP, Felipe MSS, dos Santos Feitosa L, Mendes-Giannini MJS, de Almeida Soares CM. Glyceraldehyde3-phosphate dehydrogenase of Paracoccidioides brasiliensis is a cell surface protein involved in fungal adhesion to extracellular matrix proteins and interaction with cells. Infect Immun. 2006;74:382-9.

59. Garcin ED. GAPDH as a model non-canonical AU-rich RNA binding protein. Seminars in cell and developmental biology. New York: Elsevier: 2018

60. Pereira LA, Báo SN, Barbosa MS, Da Silva JLM, Felipe MSS, De Santana JM, Mendes-Giannini MJS, De Almeida Soares CM. Analysis of the Paracoccidioides brasiliensis triosephosphate isomerase suggests the potential for adhesin function. FEMS Yeast Res. 2007:7:1381-8.

61. Miranda-Ozuna JF, Hernández-García MS, Brieba LG, Benítez-Cardoza CG, Ortega-López J, González-Robles A, Arroyo R. The glycolytic enzyme triosephosphate isomerase of Trichomonas vaginalis (TVTIM) is a surfaceassociated protein induced by glucose that functions as a laminin-and fibronectin-binding protein. Infect Immun. 2016;|Al:00538.

62. Kinnby B, Booth NA, Svensäter G. Plasminogen binding by oral streptococci from dental plaque and inflammatory lesions. Microbiology. 2008;154:924-31

63. Crowe JD, Sievwright IK, Auld GC, Moore NR, Gow NA, Booth NA. Candida albicans binds human plasminogen: identification of eight plasminogenbinding proteins. Mol Microbiol. 2003;47:1637-51.

64. Jagadeesan B, Koo OK, Kim K-P, Burkholder KM, Mishra KK, Aroonnual A, Bhunia AK. LAP, an alcohol acetaldehyde dehydrogenase enzyme in Listeria, promotes bacterial adhesion to enterocyte-like Caco-2 cells only in pathogenic species. Microbiology. 2010;156:2782-95.

65. Meza-Cervantez P, Gonzalez-Robles A, Cárdenas-Guerra RE, Ortega-Lopez J, Saavedra E, Pineda E, Arroyo R. Pyruvate: ferredoxin oxidoreductase (PFO) is a surface-associated cell-binding protein in Trichomonas vaginalis and is involved in trichomonal adherence to host cells. Microbiology. 2011:157:3469-82

66. Song $\mathrm{H}-\mathrm{O}$. Influence of $120 \mathrm{kDa}$ pyruvate: ferredoxin oxidoreductase on pathogenicity of Trichomonas vaginalis. Kor J Parasitol. 2016;54:71.

67. Mohammed MMA, Pettersen VK, Nerland AH, Wiker HG, Bakken V. Quantitative proteomic analysis of extracellular matrix extracted from mono-and dual-species biofilms of Fusobacterium nucleatum and Porphyromonas gingivalis. Anaerobe. 2017:44:133-42.

68. Sengupta N, Alam SI, Kumar B, Kumar RB, Gautam V, Kumar S, Singh L. Comparative proteomic analysis of extracellular proteins of Clostridium perfringens type A and type C strains. Infect Immun. 2010;78:3957-68.

69. Manfredi P, Renzi F, Mally M, Sauteur L, Schmaler M, Moes S, Jenö P, Cornelis GR. The genome and surface proteome of Capnocytophaga canimorsus reveal a key role of glycan foraging systems in host glycoproteins deglycosylation. Mol Microbiol. 2011:81:1050-60.

70. Gómez-Gascón L, Luque I, Olaya-Abril A, Jiménez-Munguía I, OrbegozoMedina RA, Peralbo E, Tarradas C, Rodríguez-Ortega MJ. Exploring the pan-surfome of Streptococcus suis: looking for common protein antigens. J Proteomics. 2012;75:5654-66.
71. Tracy BP, Gaida SM, Papoutsakis ET. Development and application of flow-cytometric techniques for analyzing and sorting endospore-forming clostridia. Appl Environ Microbiol. 2008;74:7497-506.

72. Jones SW, Tracy BP, Gaida SM, Papoutsakis ET. Inactivation of of in Clostridium acetobutylicum ATCC 824 blocks sporulation prior to asymmetric division and abolishes $\sigma E$ and $\sigma G$ protein expression but does not block solvent formation. J Bacteriol. 2011:193:2429-40.

73. Lütke-Eversloh T, Bahl H. Metabolic engineering of Clostridium acetobutylicum: recent advances to improve butanol production. Curr Opin Biotechnol. 2011;22:634-47.

74. Liao C, Seo S-O, Celik V, Liu H, Kong W, Wang Y, Blaschek H, Jin Y-S, Lu T. Integrated, systems metabolic picture of acetone-butanol-ethanol fermentation by Clostridium acetobutylicum. Proc Natl Acad Sci. 2015;112(27):8505-10.

75. Lemon K, Earl A, Vlamakis H, Aguilar C, Kolter R. Biofilm development with an emphasis on Bacillus subtilis. Bacterial Biofilms. Berlin: Springer; 2008. p. $1-16$.

76. Wallenius J, Maaheimo H, Eerikäinen T. Carbon 13-metabolic flux analysis derived constraint-based metabolic modelling of Clostridium acetobutylicum in stressed chemostat conditions. Bioresour Technol. 2016;219:378-86

77. Hu S, Zheng H, Gu Y, Zhao J, Zhang W, Yang Y, Wang S, Zhao G, Yang S, Jiang W. Comparative genomic and transcriptomic analysis revealed genetic characteristics related to solvent formation and xylose utilization in Clostridium acetobutylicum EA 2018. BMC Genom. 2011;12:93.

78. Sleytr UB, Sára M. Bacterial and archaeal S-layer proteins: structurefunction relationships and their biotechnological applications. Trends Biotechnol. 1997;15:20-6.

79. Đapa T, Leuzzi R, Ng YK, Baban ST, Adamo R, Kuehne SA, Scarselli M, Minton NP, Serruto D, Unnikrishnan M. Multiple factors modulate biofilm formation by the anaerobic pathogen Clostridium difficile. J Bacteriol. 2012;J:01980.

80. Dembek M, Barquist L, Boinett CJ, Cain AK, Mayho M, Lawley TD, Fairweather NF, Fagan RP. High-throughput analysis of gene essentiality and sporulation in Clostridium difficile. MBio. 2015;6:e02383.

81. Kirk JA, Gebhart D, Buckley AM, Lok S, Scholl D, Douce GR, Govoni GR, Fagan RP. New class of precision antimicrobials redefines role of Clostridium difficile S-layer in virulence and viability. Sci Transl Med. 2017;9:eaah6813.

82. Pantaléon V, Soavelomandroso AP, Bouttier S, Briandet R, Roxas B, Chu M, Collignon A, Janoir C, Vedantam G, Candela T. The Clostridium difficile protease Cwp84 modulates both biofilm formation and cell surface properties. PLoS ONE. 2015;10:e0124971.

83. Foulston L, Elsholz AK, DeFrancesco AS, Losick R. The extracellular matrix of Staphylococcus aureus biofilms comprises cytoplasmic proteins that associate with the cell surface in response to decreasing pH. MBio. 2014:5:e01667.

84. Yang C-K, Ewis HE, Zhang X, Lu C-D, Hu H-J, Pan Y, Abdelal AT, Tai PC. Nonclassical protein secretion of Bacillus subtilis in the stationary phase is not due to cell lysis. J Bacteriol. 2011;JB:05897.

85. Arora G, Sajid A, Virmani R, Singhal A, Kumar C, Dhasmana N, Khanna T, Maji A, Misra R, Molle V. Ser/Thr protein kinase PrkC-mediated regulation of GroEL is critical for biofilm formation in Bacillus anthracis. NPJ Biofilms Microbiomes. 2017;3:7.

86. Jain S, Smyth D, O'Hagan BM, Heap JT, McMullan G, Minton NP, Ternan NG. Inactivation of the dnaK gene in Clostridium difficile $630 \triangle$ erm yields a temperature-sensitive phenotype and increases biofilm-forming ability. Sci Rep. 2017;7:17522.

87. Riebe $\mathrm{O}$, Fischer R-J, Wampler DA, Kurtz DM Jr, Bahl H. Pathway for $\mathrm{H}_{2} \mathrm{O}_{2}$ and $\mathrm{O}_{2}$ detoxification in Clostridium acetobutylicum. Microbiology. 2009;155:16-24.

88. Okshevsky M, Meyer RL. The role of extracellular DNA in the establishment, maintenance and perpetuation of bacterial biofilms. Crit Rev Microbiol. 2015;41:341-52.

89. Turnbull L, Toyofuku M, Hynen AL, Kurosawa M, Pessi G, Petty NK, Osvath SR, Cárcamo-Oyarce G, Gloag ES, Shimoni R. Explosive cell lysis as a mechanism for the biogenesis of bacterial membrane vesicles and biofilms. Nat commun. 2016;7:11220. 